\title{
Load of the slipper-swash plate kinematic pair of an axial piston pump
}

\author{
Tadeusz Złoto ${ }^{1, *}$, Konrad Kowalski ${ }^{1}$ \\ ${ }^{1}$ Czestochowa University of Technology,Institute of Mechanical Technologies, Armii Krajowej 21, \\ Czestochowa,Poland
}

\begin{abstract}
The paper presents problems related to the twisting moment of the slipper. The load of the slipper and the piston has been presented and the complex formula of twisting moment of the slipper has been established. Achieved results has been presented graphically. The conducted research has indicated that the value of the twisting moment relays on both the exploitation and geometrical parameters.
\end{abstract}

Keywords: load, slipper-swash plate, axial piston pump, hydrostatic relief, twisting moment

\section{Introduction}

Axial piston pumps have many applications in different industrial hydraulic systems and can be used at the highest pressures and powers. Axial piston pumps are expensive, but provide exceptional performance and high efficiencies. The reliability and durability of an axial piston pump depends significantly on the condition of hydrostatic supports. Hydrostatic slipper of an axial piston pump is of relatively small size and transfers large loads in tough conditions. The swash plate is inclined at a certain angle with respect to the axis of piston symmetry. Because the piston load is located off the axis, the presence of friction and inertia forces can turn the slipper over.

A satisfactory scientific mathematical model of the whole process of designing hydrostatic slippers has been missed so far. Pump manufacturers must therefore rely on laborious and time-consuming empirical studies $[1,2]$. The increasing demand for new types of pumps and for improving their performance necessitates developing universal and reliable constructions of high efficiency.

\section{The piston load model}

During normal operation of a piston-cylinder unit in a swash-plate axial piston pump, the hydrostatic slipper is loaded by the radial force coming from a discharge pressure (fig. 1).

\footnotetext{
*Corresponding author: zlotot@o2.pl

Reviewers: Zuzana Murčinková, Jaroslav Zapoměl
} 


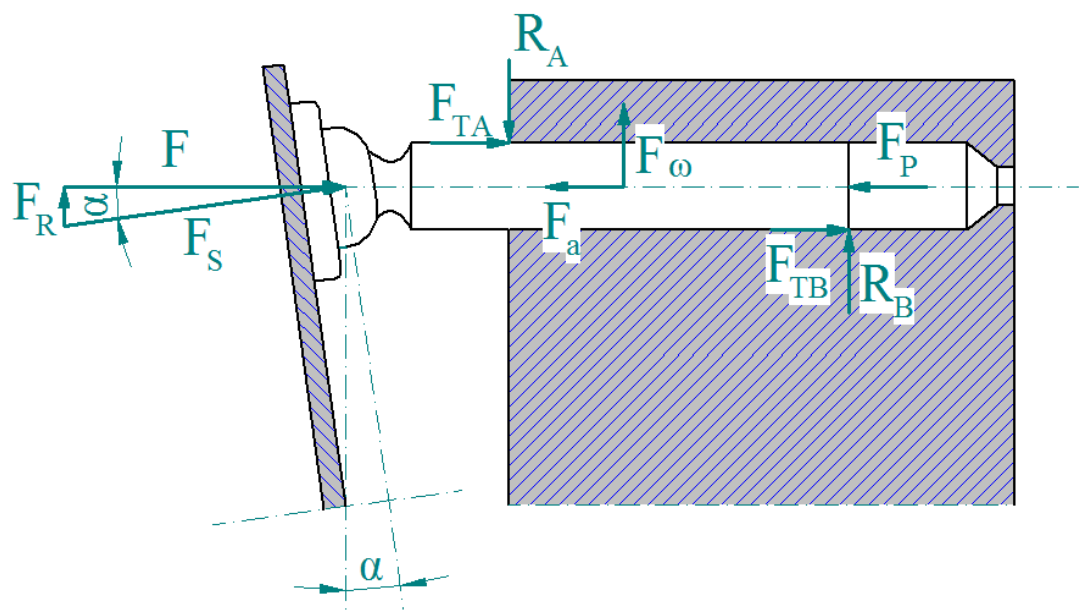

Fig. 1. Force distribution in a piston-cylinder unit

The radial force $F_{R}$ results in inclined position of the piston and therefore results in reactions $R_{A}$ and $R_{B}$ of large value [3]. As an effect, friction force $F_{T}$ occurs. This friction force was obtained from $[4,5]$ :

$$
F_{T}=\mu\left(R_{A}+R_{B}\right)
$$

where $\mu$ - friction coefficient between the piston and the cylinder.

In calculation model there have been assumed the following forces: force $F_{p}$ coming from the discharge pressure, dynamic force $F_{a}$ that occurs as a result of velocity changes of a reciprocating piston unit, centrifugal inertia force $F_{\omega}$ coming from rotation of the piston unit round the rotor axis, spring force $F_{s p r}$ pushing the piston unit to the swash plate, force $F_{s}$ pressing the slipper against the swash plate, friction forces between the piston and the $\mu R_{A}$ and $\mu R_{B}$ and friction force $F_{T S}$ between the slipper and the swash plate. Reactions $R_{A}$ and $R_{B}$ were assumed as passive forces.

\section{Hydrostatic relief of the slipper}

The slipper performs the task of transferring all the axial forces acting upon the piston system, and it is desirable to minimize energy losses and wear-out, and to maximize reliability within the full range of the piston pump reliability $[6,7]$. The slipper surface can have various shapes [8]. Regardless of the shape, there should be a central neck connecting the slipper with the piston pressure chamber.

Standard hydrostatic slipper (Fig. 2) has an internal and external radius. The geometrical parameters of the hydrostatic slipper should be selected in such a way that the load carrying force resulting from the hydrostatic pressure field takes over $90 \div 95 \%$ of the normal load [8] and the hydrodynamic force takes over the other $5 \div 10 \%$ of the load. In the derivation of the formula for the pressure change on the slipper sealing surface it is assumed that the mating surfaces are ideally smooth, the flow is laminar and isothermal. The pressure in a typical hydrostatic slipper can be described by the following formula: 


$$
p=p_{o} \frac{\ln \frac{r_{2}}{r}}{\ln \frac{r_{2}}{r_{1}}}
$$

where:

$p, p_{0}$ - the pressure along the slipper radius and in the slipper chamber, respectively, $r_{2}, r, r_{l}$ - the external, current and internal radius of the slipper, respectively.

The repulsive force of a typical hydrostatic slipper is [9]:

$$
F_{o}=p_{o} \frac{\pi}{2} \cdot \frac{r_{2}^{2}-r_{1}^{2}}{\ln \frac{r_{2}}{r_{1}}}
$$

The slipper construction affects power losses. The total power loss consists of the power lost due to leakage and friction loss. The gap height $h_{s}$ (Fig. 2) is of the greatest importance. With the increase in $h_{s}$ the mechanical losses decrease, the volumetric losses, however, dramatically increase. Mechanical losses can be reduced by reducing the surfaces surrounding the gap. Another way to reduce mechanical losses is to use slippers with additional bearing surfaces [10], that enable significant hydrodynamic effects on a flat surface.

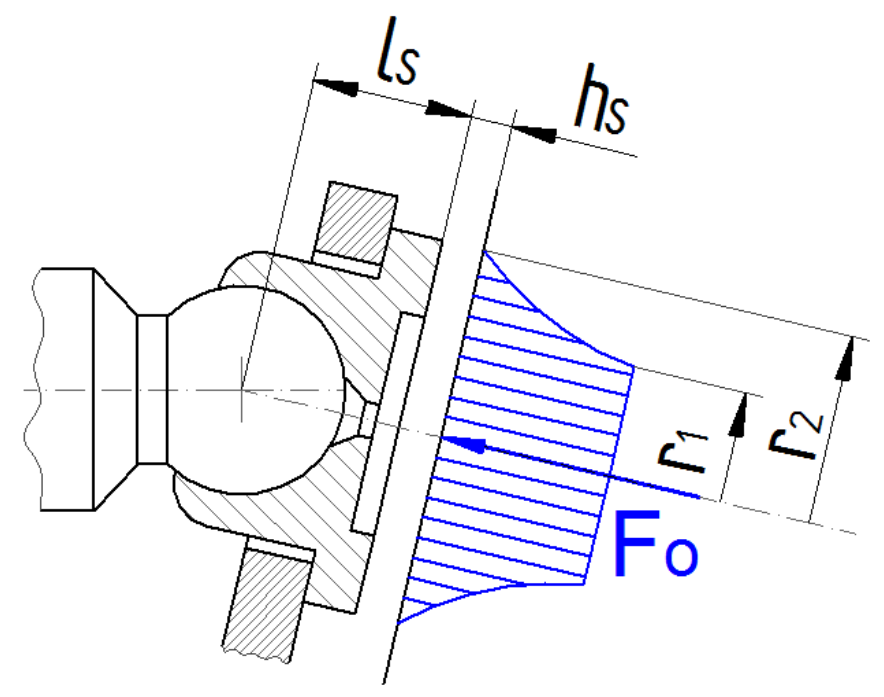

Fig. 2. Hydrostatic relief of the slipper

It is difficult to design an axial piston pump of variable yield, in which it is necessary to transfer variable loads, resulting from the changes in the inclination angle a of the swash plate.

\section{Simulation of a slipper's load}

During operation the slipper is under the effect of twisting moment, which is trying to turn the slipper over. 


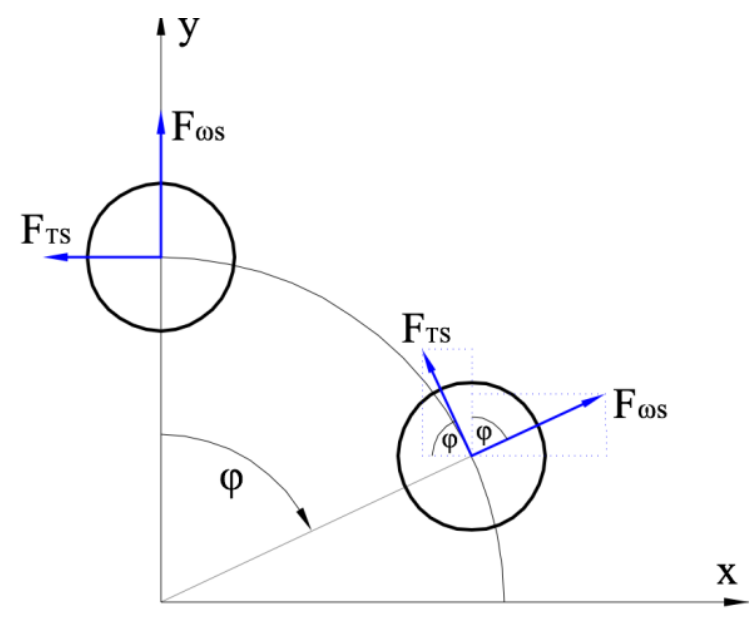

Fig. 3. Forces acting on the slipper

Fig 3 presents friction force $F_{T S}$ between the slipper and the swash plate and the centrifugal inertia force $F_{\omega s}$ acting upon the slipper. The friction force is obtained by multiplication of pressing force (difference between the normal force $F_{s}$ and the relief force $F_{o}$ of the slipper) and the friction coefficient $\mu_{s}$ :

$$
F_{T S}=\mu_{s}\left[\frac{0.25 \pi d^{2} p_{1}+\mu_{T}\left(R_{A}+R_{B}\right)+F_{s p r}+m_{c} \omega^{2} r_{p} \tan \alpha \cos \varphi}{\cos \alpha}-C_{p} \frac{\pi p_{1}}{2}\left(\frac{r_{2}^{2}-r_{1}^{2}}{\ln \frac{r_{2}}{r_{1}}}\right)\right]
$$

where $C_{p}$ - the pressure drop between the cylinder and the slipper chamber.

Centrifugal inertia force can be obtained from:

$$
F_{\omega s}=m_{s}\left(\frac{\omega \cos \alpha}{\cos ^{2} \varphi+\cos ^{2} \alpha \cdot \sin ^{2} \varphi}\right)^{2} r_{p} \sqrt{1+\tan ^{2} \alpha \cdot \cos ^{2} \varphi}
$$

The resultant force acting upon the slipper was obtained as a geometrical sum of the projections of the component forces in the set of coordinates $x y$ :

$$
F_{W}=\sqrt{F_{W X}^{2}+F_{W Y}^{2}}
$$

After substituting and bringing inertia force onto the plane on which the slipper and the swash plate mate:

$$
F_{W}=\sqrt{\left(-F_{T S} \cos \varphi+F_{\omega s} \frac{l_{s}}{l_{s c}} \sin \varphi\right)^{2}+\left(F_{T S} \sin \varphi+F_{\omega s} \frac{l_{s}}{l_{s c}} \cos \varphi\right)^{2}}
$$

where $l_{s}$ - the distance between the coupling centre and the mating surface, $l_{s c}$ - the distance between the gravity centre and the mating surface.

The slipper's twisting moment is as follows:

$$
M_{s}=l_{s} \cdot F_{W}
$$

Applying formula 8 an influence of discharge pressure, friction coefficient between the slipper and the swash plate, mass of the slipper and the angular velocity, on value of the 
twisting moment $M_{s}$ of the slipper were analysed. The following initial data were assumed in the computations:

- discharge pressure $p_{t}=p_{1}=32 \mathrm{MPa}$,

- friction coefficient $\mu_{s}=0.003$ [11],

- friction coefficient $\mu_{T}=0.1$ [6],

- piston diameter $d=0.015 \mathrm{~m}$,

- mass of the slipper $m_{s}=0.025 \mathrm{~kg}$,

- mass of the slipper and the piston $m_{c}=0.07 \mathrm{~kg}$,

- spring force $F_{s p r}=75 \mathrm{~N}$,

- angular velocity $\omega=150 \mathrm{rad} / \mathrm{s}$,

- the pressure drop of $10 \%$ between the cylinder and the slipper operating $\rightarrow C_{p}=0.9$ [8],

- the value of reaction $R_{A}$ and $R_{B}$ depends on the cylinder block rotation angle $\varphi$ [12].

The achieved results are shown in Fig. 4. The conducted analyses has shown that the angular velocity $\omega$ of the cylinder block has the highest influence on value of the twisting moment $M_{s}$ of the slipper. With the increase of the angular velocity, the twisting moment increases. Significant impact on twisting moment has the slipper mass. If the slipper mass is higher, the twisting moment is higher too. Furthermore, friction coefficient between the slipper and the swash plate and the discharge pressure has smaller influence on the twisting moment of the slipper.

a)

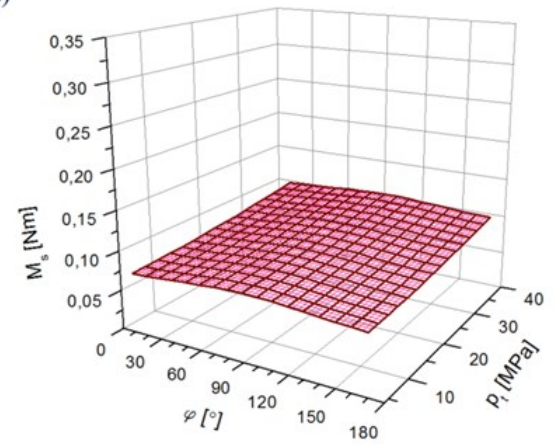

c)

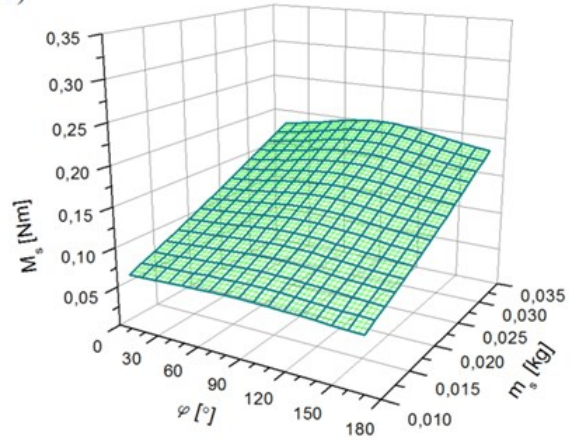

b)

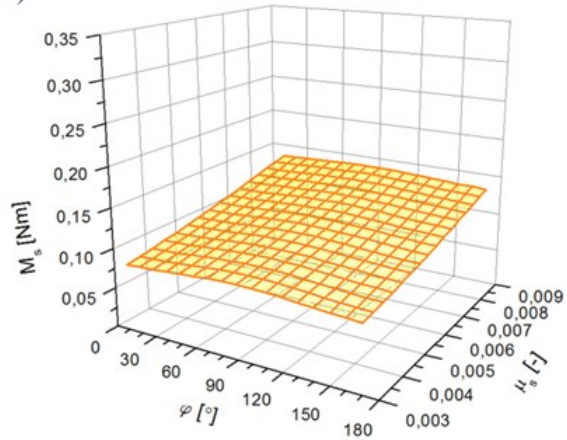

d)

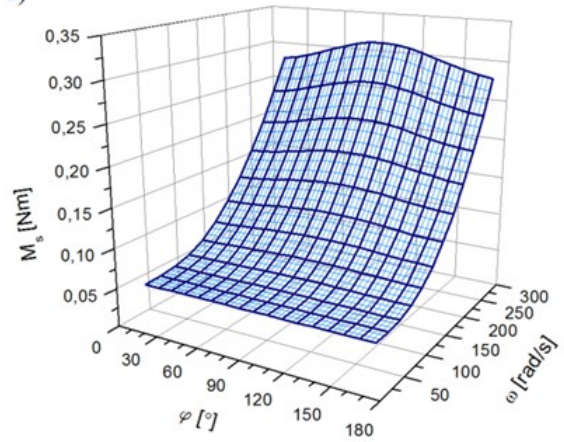

Fig. 4. Twisting moment $M_{s}$ of the slipper in the pressure zone depending on: a) discharge pressure, b) friction coefficient between the slipper and the swash plate, c) mass of the slipper, d) angular velocity of the cylinder block 
Twisting moment $M_{s}$ has negative influence on the operation of axial piston pumps, and deteriorates the mating conditions of the slipper and the swash plate. The conducted research has shown that the twisting moment tends to turn the slipper over.

Fig. 5 presents an example of damages on the slipper surface because the oil film between the slipper and the swash plate has disappeared. The pump was turn on periodically. The reason of this destruction is the wrong installation of the pump, with leak drain channel on the wrong side of the pump. Each time the pump was turn on, especially after longer period of being switched off, the pump worked dry, and the twisting moment turned over all slippers, pressing them onto the swash plate.

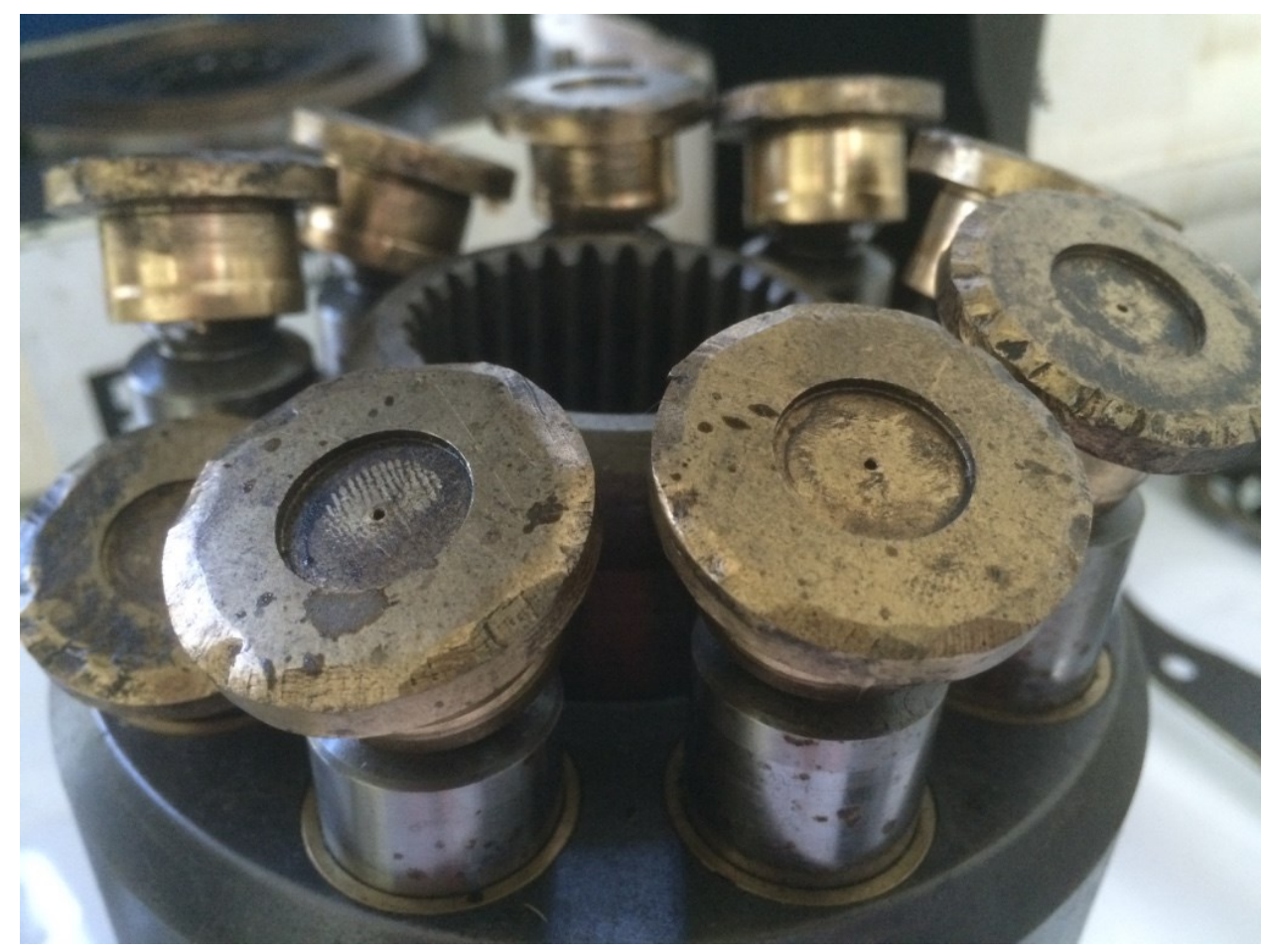

Fig. 5. Hydrostatic slippers of an axial piston pump destroyed due to metal contact with a swash plate surface

\section{Conclusions}

The hydrostatic slipper of pistons machines transfers large loads and is loaded by the twisting moment of significant value. The angular speed of the cylinder block has the highest influence on the value of the twisting moment of the slipper. Apart from this, significant influence on the value of the twisting moment have friction coefficient between the slipper and the swash-plate, mass of the slipper and the discharge pressure. Another design parameters like mass of a piston unit and spring force, as well as exploitation parameters like the inclination angle of a swash plate and friction force between piston and the cylinder have small influence on the value of the twisting moment of the slipper. 


\section{References}

1. E. Brzuchowski, H. Kertyńska, D. Kraszewski, The results of model research and analysis of the influence of friction on the load state of hydrostatic bearing elements. (In Polish : Wyniki badań modelowych oraz analiza wptywu tarcia na stan obciażenia elementów łożysk hydrostatycznych). Przeglad Mechaniczny 21, (1974)

2. K.T. Renius, Experimental investigations on sliding shoes of axial piston machines (In German: Experymentelle Untersuchungen an Gleitschuhen von Axialkolbenmaschinen). Ölhydraulik und Pneumatik 3, (1973)

3. A. Osiecki, Hydrostatic machines drive (In Polish: Hydrostatyczny napęd maszyn). WNT, Warszawa (1998)

4. Ch. Kögl, Adjustable hydrostatic displacement units in the speed and torque control circuit on the mains with adapted supply pressure (In German: Verstellbare hydrostatische Verdrängereinheiten im Drehzahl- und Drehmomentregelkreis am Netz mit angepaßtem Versorgungsdruck). Dissertation RWTH, Aachen (1995)

5. S. Stryczek, Hydrostatic drive (In Polish : Napęd hydrostatyczny). WNT, Warszawa, 1, (1995)

6. W. Balas, Hydrostatic bearings in axial piston pumps (In Polish: Łożyska hydrostatyczne w osiowych pompach tlokowych). Przegląd Mechaniczny 11, (1976)

7. A. Osiecki, Osiecki L., Development works on a new construction of axial piston pumps (In Polish : Prace rozwojowe nad nowa konstrukcja pomp wielotłoczkowych osiowych). Przegląd Mechaniczny 4, (1998)

8. J. Ivantysyn, M. Ivantysynova, Hydrostatic Pumps and Motors. Akademia Books International, New Delhi (2001)

9. Z. Szydelski, J. Olechowicz, Elements of hydraulic and pneumatic drive and control (In Polish : Elementy napędu i sterowania hydraulicznego i pneumatycznego). WNT, Warszawa (1986)

10. H. Lachner, Hydrostatic bearings in axial piston machines (In Polish : Hydrostatische Lagerungen in Axialkolbenmasinen). Ölhydraulik und Pneumatik 8, (1974)

11. J. Niegoda, Study of the possibility of using pistons with non-articulated hydrostatic support in axial multi-piston pumps and motors (In Polish: Badanie możliwości zastosowania tłoków z bezprzegubowym podparciem hydrostatycznym $w$ pompach i silnikach wielotloczkowych osiowych). Dysertacja, Gdańsk (1977)

12. T. Złoto, Modeling of hydrostatic relief and analysis of flow phenomena in the axial displacement of the axial piston pump (In Polish: Modelowanie odciazienia hydrostatycznego $i$ analiza zjawisk przeptywowych $w$ szczelinie rozrzadu tarczowego pompy wielotłoczkowej osiowej). Seria monografie 133, Częstochowa (2007) 